\title{
RANCANG BANGUN APLIKASI EDUKASI VITAMIN PADA BUAH DAN SAYUR BERBASIS ANDROID
}

\author{
Azqia Zahra Attohiroh ${ }^{1}$, Akhmad Aris Tantowi ${ }^{2}$, Agus Wilson ${ }^{3}$ \\ Program Studi Teknik Informatika, Fakultas Teknik dan Ilmu Komputer, \\ Universitas Indraprasta PGRI \\ Jalan Raya Tengah No 80, Kelurahan Gedong, Pasar Rebo, Jakarta Timur \\ azqiaz040@gmail.com¹ , suksesbesarsekali@gmail.com², wilsonaw2580@gmail.com³
}

\begin{abstract}
Abstrak
Rumusan masalah dalam penelitian ini yaitu bagaimana membuat aplikasi berbasis android dengan desain antarmuka dan materi yang mudah dimengerti oleh masyarakat mengenai pengetahuan tentang vitamin pada buah dan sayur. Penelitian ini bertujuan untuk memberikan kemudahan bagi masyarakat dalam mengenal tentang vitamin pada buah-buahan dan sayur-sayuran agar masyarakat mengetahui manfaatnya untuk tubuh. Adapun yang menjadi latar belakang penelitian yaitu saat ini banyak masyarakat yang belum mengetahui betapa pentingnya vitamin bagi tubuh padahal banyak yang dapat dimanfaatkan untuk mendapatkan vitamin yang kita butuhkan untuk tubuh seperti mengkonsumsi buah dan sayur, biasanya pengetahuan ini dapat diakses melalui buku ataupun majalah. Hasil penelitian ini yaitu memberikan kemudahan akses informasi pada masyarakat dengan memanfaatkan kemajuan teknologi maka masyarakat dapat mengakses informasi dengan mudah di smartphone karena aplikasi ini menampilkan informasi tentang vitamin pada buah dan sayur serta dilengkapi kuis yang berisi pertanyaan seputar buah dan sayur yang dapat meningkatkan pengetahuan.
\end{abstract}

Kata Kunci: Aplikasi, Android, Vitamin, Buah dan Sayur

\begin{abstract}
The formula of the problem in this study is how to create android-based applications with interface design and materials that are easily understood by the public about the knowledge of vitamins in fruits and vegetables. This research aims to provide convenience for the public in knowing about vitamins in fruits and vegetables so that the public knows the benefits for the body. As for the background of the research, today many people do not know how important vitamins are for the body when many can be used to get vitamins. we need for the body such as consuming fruits and vegetables, usually this knowledge can be accessed through books or magazines. The results of this study are to provide easy access to information to the public by utilizing technological advances so that the public can access information easily on smartphones because this application displays information about vitamins in fruits and vegetables and is equipped with quizzes containing questions about fruits and vegetables that can increase knowledge.
\end{abstract}

Keywords: Application, Android, Vitamin, Fruits and Vegetables

\section{PENDAHULUAN}

Berkembangnya Ilmu Pengetahuan dan Teknologi (IPTEK) pada era globalisasi seperti saat ini, pemanfaatannya sangat cepat dan menghasilkan inovasi -inovasi baru yang harus diimbangi dengan kemampuan beradaptasi terhadap teknologi tersebut. Salah satu teknologi yang sangat berkembang pesat dan sangat dibutuhkan untuk kehidupan sehari-hari saat ini yaitu smartphone. Smartphone merupakan sebuah handphone yang didalamnya sudah tertanam sebuah sistem operasi teknologi terbaru dan memiliki fungsi yang dapat memudahkan kegiatan sehari-hari (Jocom, 2013). Ada banyak berbagai macam sistem operasi yang tercipta saat ini (Atmodjo \& Krisjanti, 2016) sistem operasi yang dikenal saat ini adalah Android dan Ios, Penelitian ini membuat aplikasi dengan salah satu sistem operasi mobile yang sangat diminati yaitu sistem operasi android. Android adalah sistem operasi telepon seluler yang berbasis Linux (Nazruddin Safaat, 2011). Berbagai keunggulan dari sistem operasi android adalah aplikasi sistem operasi di dalamnya dapat diubah sesuai keinginan kita sendiri dan banyaknya aplikasi komputer yag sudah tersedia untuk smartphone android. 
Pemanfaatan teknologi dari segi pendidikan mungkin yang dibutuhkan saat ini, karena minat belajar saat ini akan lebih meningkat dengan adanya teknologi yang berkembang seperti mobile phone atau smartphone. Seiring berkembangnya zaman, sekarang belajar tidak hanya terfokus dengan buku, Namun melalui smartphone kita dapat mengakses berbagai ilmu pengetahuan yang kita perlukan (Chusna, 2017). Ringkas kata kemajuan teknologi saat ini benar-benar telah diakui dan dirasakan memberikan banyak kemudahan dan kenyamanan bagi kehidupan manusia (Dwiningrum, 2012) .

Peneliti ingin membuat aplikasi ini dikarenakan kurangnya pemahaman masyarakat akan penting nya mengkonsumsi buah dan sayur karena buah dan sayur mengandung vitamin serta manfaat yang berguna bagi kesehatan tubuh. Sayuran dan buah-buahan merupakan sumber berbagai vitamin, mineral dan serat pangan. Sebagian vitamin, mineral yang terkandung dalam sayuran dan buahbuahan berperan sebagai antioksidan atau penangkal senyawa jahat dalam tubuh. Berbeda dengan sayuran, buah-buahan juga menyediakan karbohidrat terutama berupa fruktosa dan Pengembangan glukosa. Sayur tertentu juga menyediakan karbohidrat, seperti wortel dan kentang sayur. Sementara buah tertentu juga menyediakan lemak tidak jenuh seperti alpukat dan buah merah (Firmansyah, 2017).

Aplikasi ini berisi tentang vitamin dan manfaat yang terkandung dalam buah dan sayur dan aplikasi ini disertai kuis yang berisi pertanyaan tentang materi yang sudah dijelaskan sebelumnya dalam aplikasi tersebut. Dengan itu peneliti berharap dengan membuat aplikasi edukasi vitamin pada buah dan sayur berbasis android ini dapat meningkatkan minat belajar, menyediakan sarana bagi orang tua, orang dewasa dan anak -anak yang ingin mengetahui tentang vitamin pada buah dan sayur serta manfaatnya dimanapun dan kapanpun.

\section{PENELITIAN RELEVAN}

Penelitian pertama adalah penelitian yang dilakukan oleh Chairul Akbar Firdaus, program studi Informatika, Universitas Indraprasta PGRI pada tahun 2018. dengan judul Perancangan Aplikasi Edukasi Pengenalan Nama Hewan dan Buah-Buahan Berbasis Android Pada TPQ Nurul Iman, Tujuan penelitian aplikasi ini adalah dapat mempermudah siswa untuk belajar mengenal nama hewan dan buah-buahan dengan perangkat android yang dapat digunakan dimana saja dan kapan saja serta mempermudah tenaga kerja TPQ Nurul Iman dalam memberi pembelajaran untuk siswa. Para pengajar dapat dengan mudah memperkenalkan nama ilmiah hewan dan tumbuhan dengan cara menginstal aplikasi nama ilmiah hewan dan tumbuhan ini di perangkat seluler (Furqan, 2015). Penelitian yang kedua adalah penelitian yang dilakukan oleh Muhammad Taufik Yulianto, dengan judul Aplikasi Mobile Dokter Gizi Berbasis Android, Tujuan aplikasi ini masyarakat dapat mengetahui status gizi, bayi, balita, remaja, dewasa dan lansia dengan hanya aplikasi android. Aplikasi adalah suatu alat yang mempunyai fungsi khusus berdasarkan kemampuan yang dimilikinya untuk membantu melakukan suatu pekerjaan bagi pengguna nya (Sutabri, 2012).

\section{METODE PENELITIAN}

Metode penelitian adalah beberapa langkah yang ditempuh dengan mengumpulkan berbagai informasi berupa data untuk pemecahan masalah dan menemukan jawaban dari masalah yang terjadi. Peneliti dalam penelitiannya menggunakan metode grounded research. Menurut (Sugiyono, 2016), metode grounded research yaitu suatu metode penelitian berdasarkan pada fakta dan menggunakan analisis perbandingan dengan tujuan mengadakan generalisasi empiris, menetapkan konsep, membuktikan teori, mengembangkan teori, pengumpulan dan analisis data dalam waktu yang bersamaan. Dalam penelitian, adapun langkah-langkah yang dilakukan untuk mengembangkan sistem dalam penyusunan ini adalah metode dalam pengumpulan data, Data studi multi kasus diperolah dari wawancara, observasi dan mempelajari berbagai dokumen yang terkait dengan topik yang diteliti (Sugiarto, 2015). Untuk memperoleh informasi maka peneliti melakukan studi pustaka, yaitu mencari bahan-bahan yang relevan dengan objek yang akan diteliti.

Pengumpulan data dari kutipan buku-buku, situs-situs internet dan hasil laporan dari bahan lain yang berhubungan dengan android. Lalu selanjutnya menganalisa kebutuhan aplikasi dengan cara melakukan observasi terhadap beberapa website tentang vitamin buah-buahan dan sayur-sayuran serta manfaatnya yang ada. Selanjutnya dirancang dan diimplementasikan aplikasi edukasi vitamin pada buah-buahan dan sayur-sayuran yang dikembangkan memakai situs website yang 
menyediakan tools yaitu kodular. Kemudian dilakukan pengujian terhadap sistem tersebut sampai semua tahap selesai. Dilanjutkan dengan pemeliharaan sistem yang telah siap digunakan.

\section{HASIL DAN PEMBAHASAN}

Dengan melihat permasalahan yang ada dimasyarakat sekarang ini masih minimnya pengetahuan dalam mempelajari vitamin dan manfaat pada buah dan sayur serta banyak diantaranya yang belum pernah menggunakan aplikasi tentang pengenalan edukasi vitamin pada buah dan sayur. Maka dari itu peneliti memperkenalkan salah satu media digital yang dapat digunakan untuk memuat informasi tentang pengenalan jenis sayur-sayuran yaitu media teknologi android.

Berikut adalah perancangan flowchart untuk Aplikasi Edukasi Vitamin Pada Buah-Buahan dan Sayur-Sayuran Berbasis Android.

\section{Menu Utama Aplikasi}

Flowchart Menu Utama Aplikasi

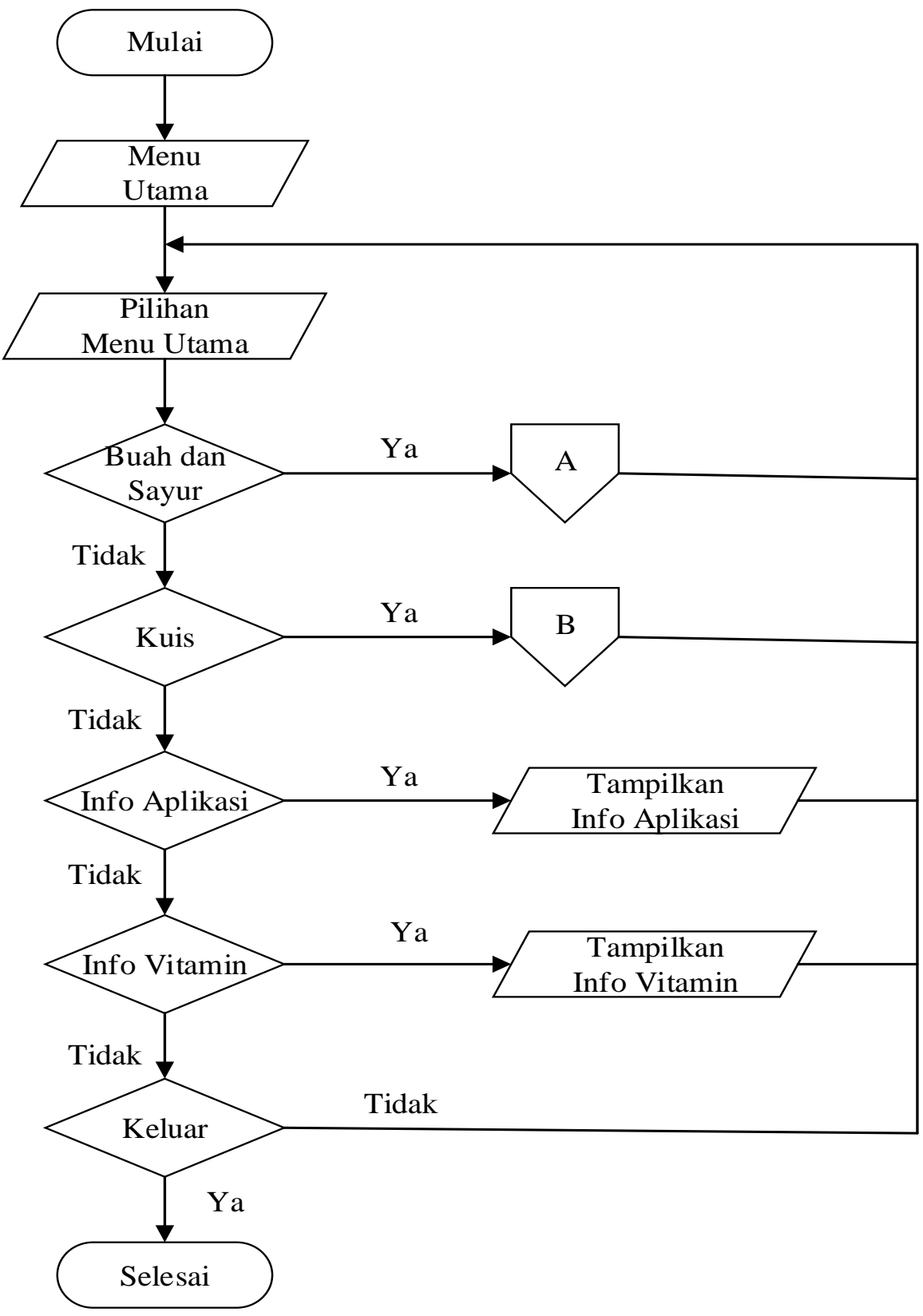

Gambar 1. Flowchart Tampilan Menu Utama 


\section{Menu Buah dan Sayur}

Flowchart Menu Buah dan Sayur

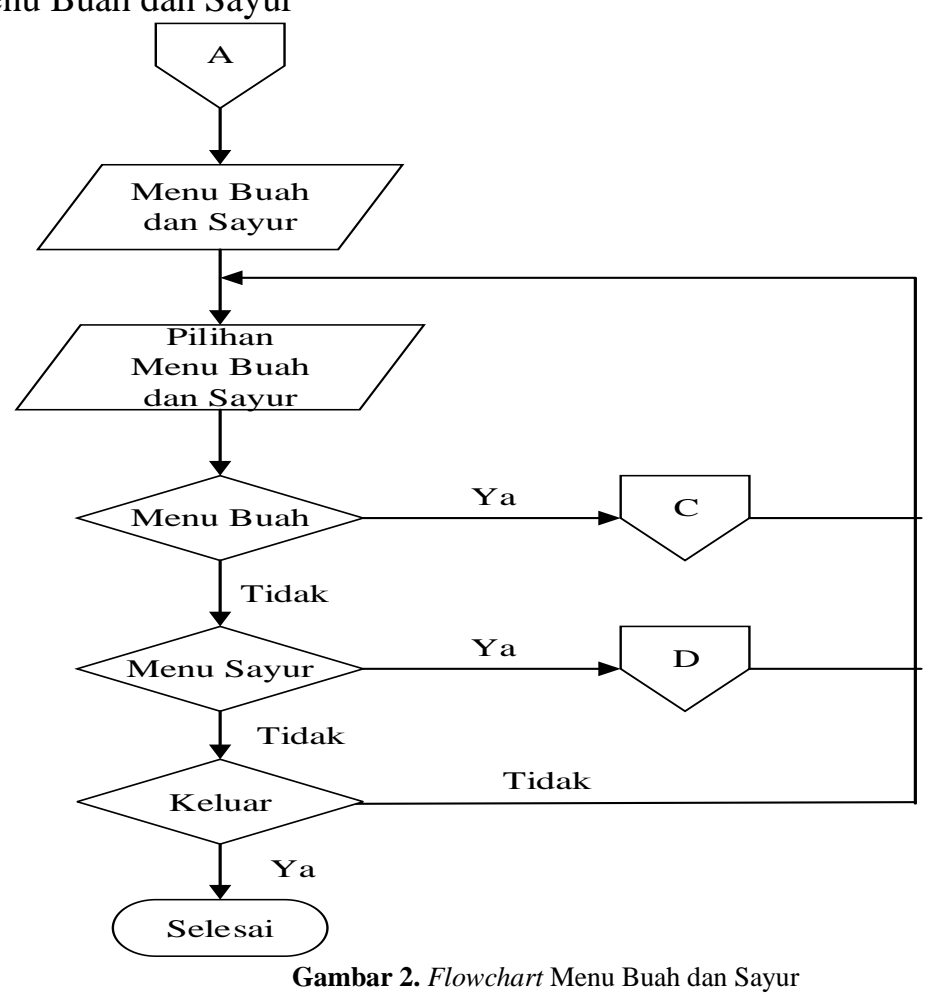

\section{Menu Buah}

Flowchart Menu Buah

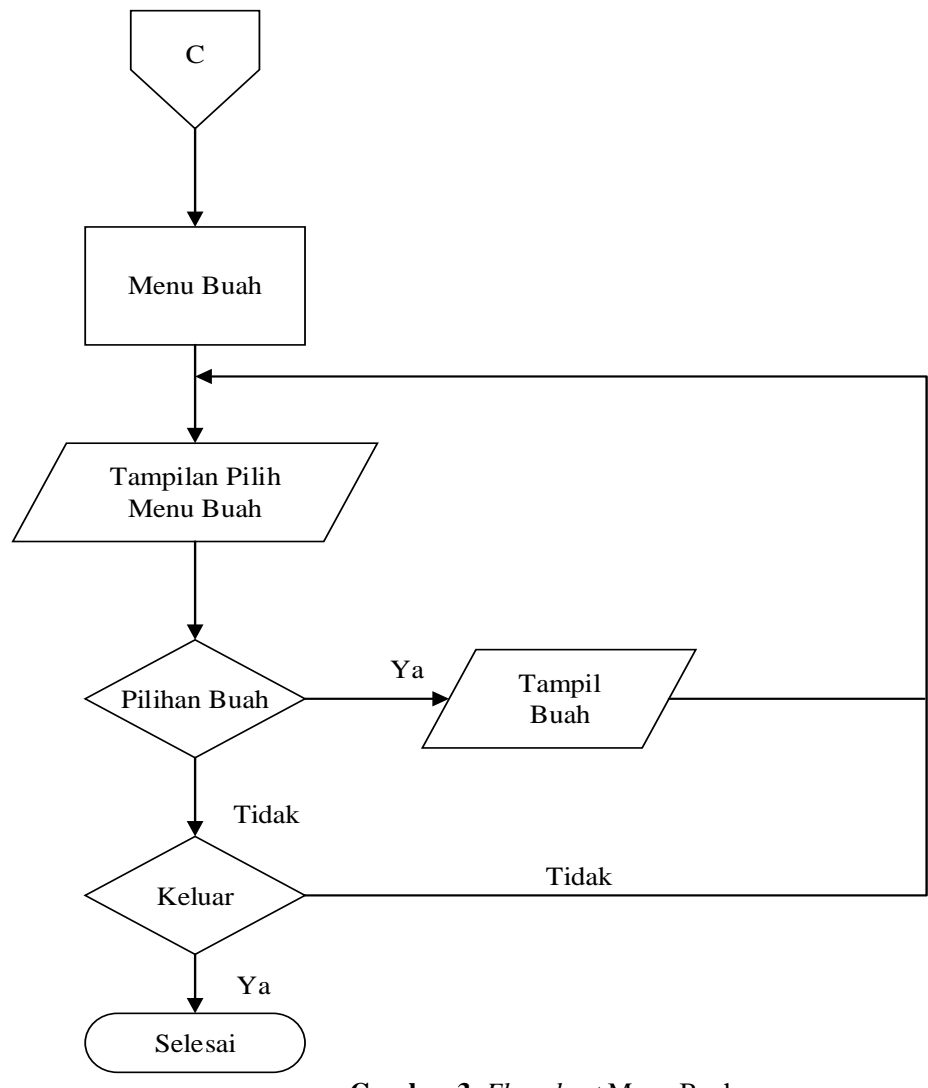

Gambar 3. Flowchart Menu Buah 


\section{Menu Sayur}

Flowchart Menu Sayur

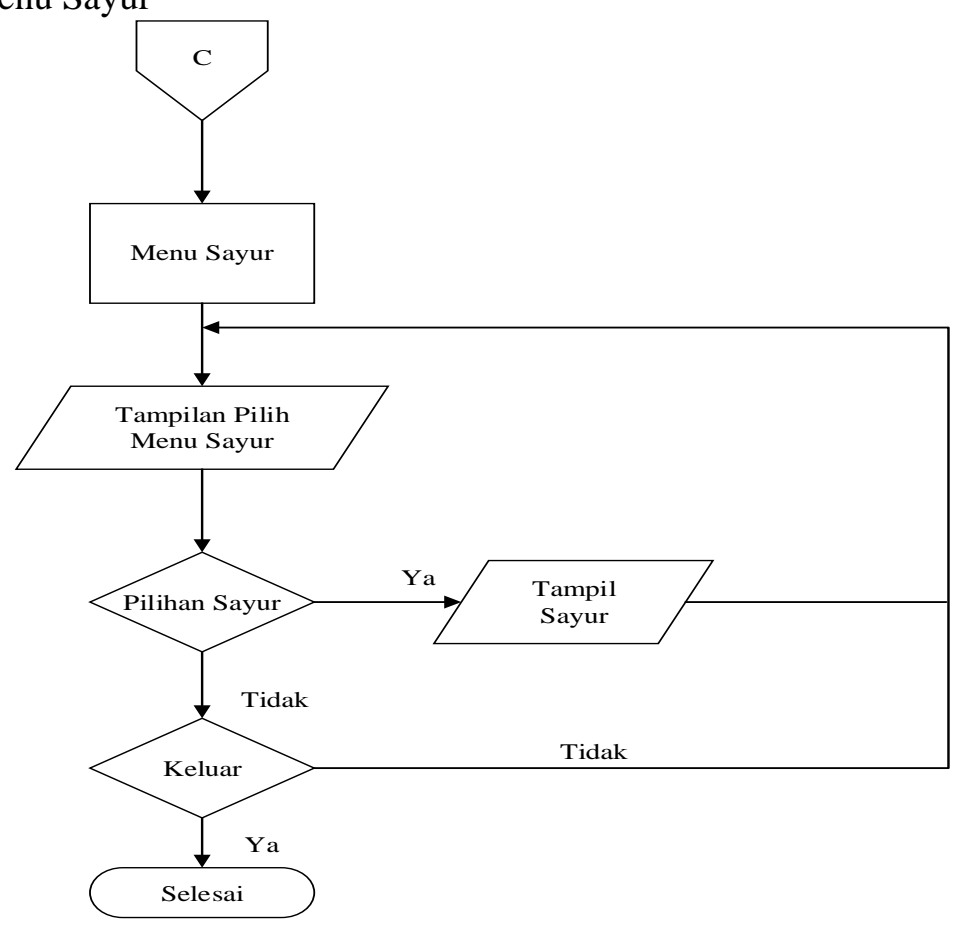

Gambar 4. Flowchart Menu Sayur

\section{Menu Kuis}

Flowchart Menu Kuis

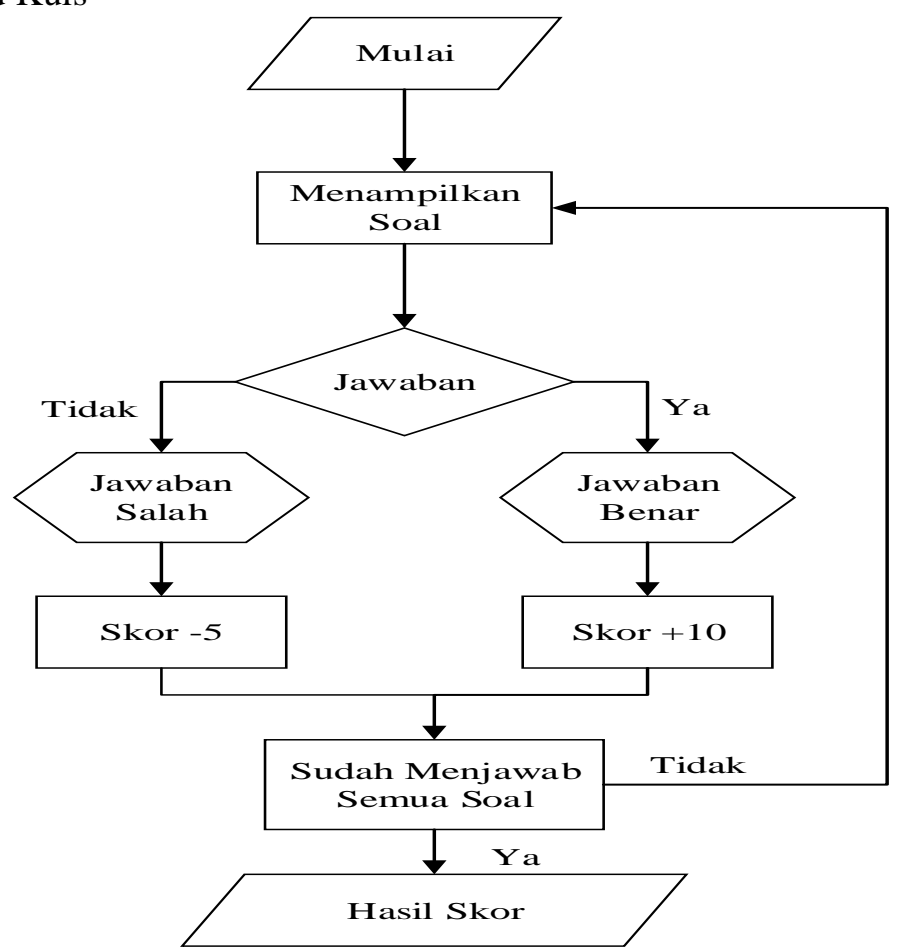

Gambar 5. Flowchart Menu Kuis

Untuk pembuatan Aplikasi edukasi vitamin pada buah-buahan dan sayur-sayuran ini peneliti menggunakan situs website yang menyediakan tools yaitu kodular dan melakukan uji coba program di smartphone berbasis android. Berikut tampilan hasil uji coba program. 


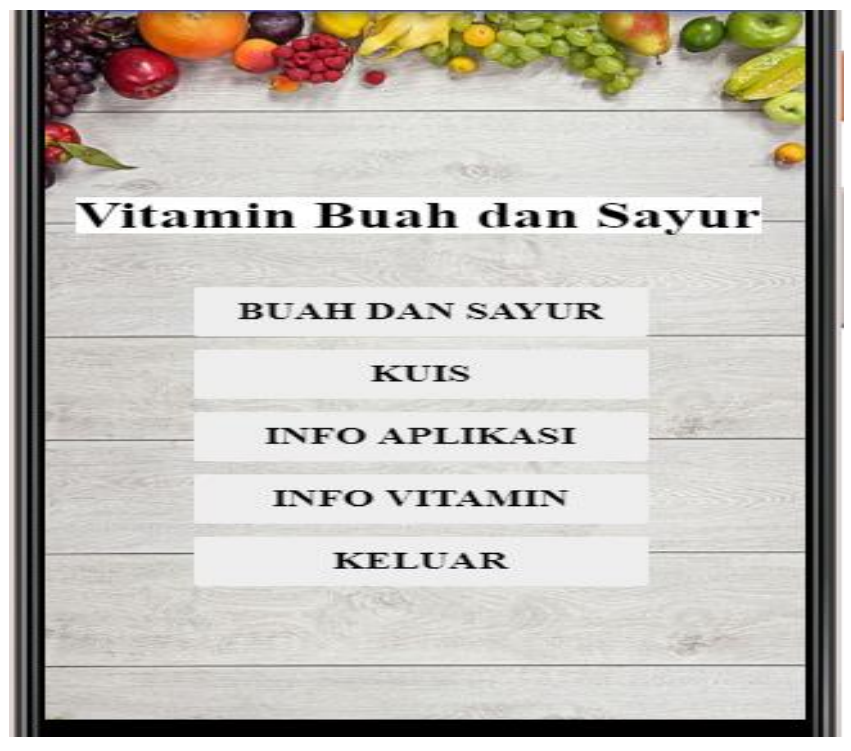

Gambar 6. Tampilan Menu Utama

Halaman menu utama ini terdiri dari 5 button yaitu button buah dan sayur, button kuis, button info aplikasi, button info vitamin dan button keluar.

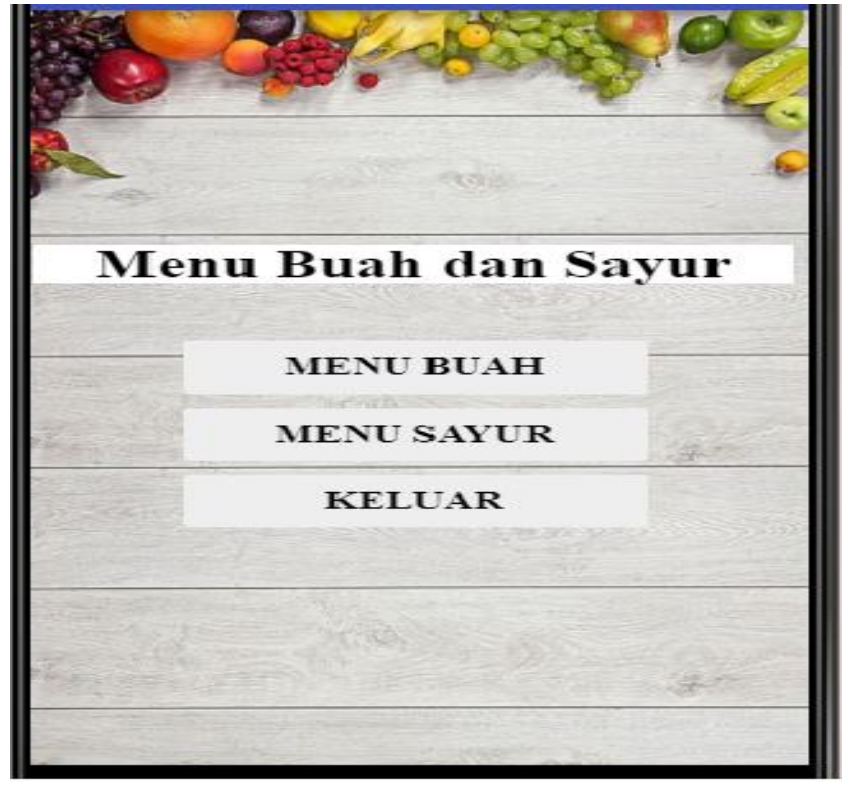

Gambar 7. Tampilan Menu Buah dan Sayur

Halaman Menu buah dan sayur terdiri dari tiga button yaitu Menu Buah, Menu Sayur dan Keluar. 


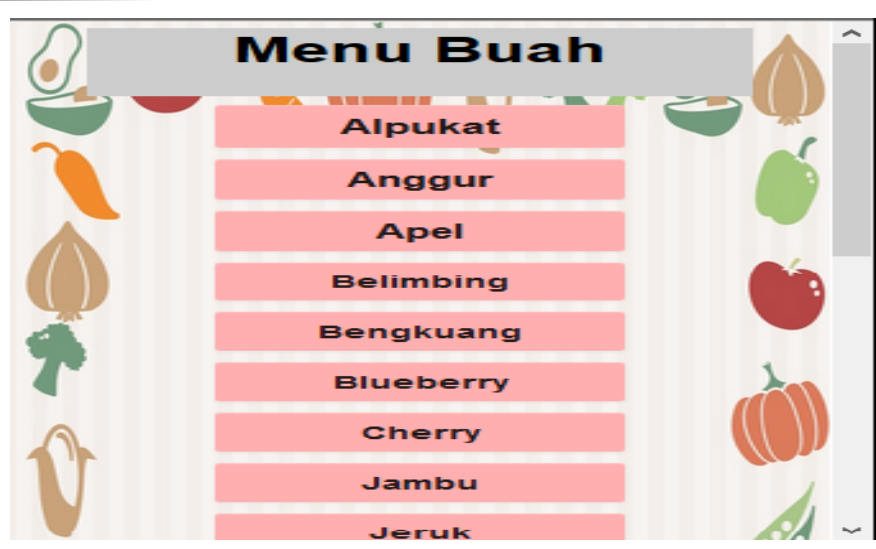

Gambar 8. Tampilan Menu Buah

Halaman Menu Buah ini berisikan beberapa pilihan menu buah

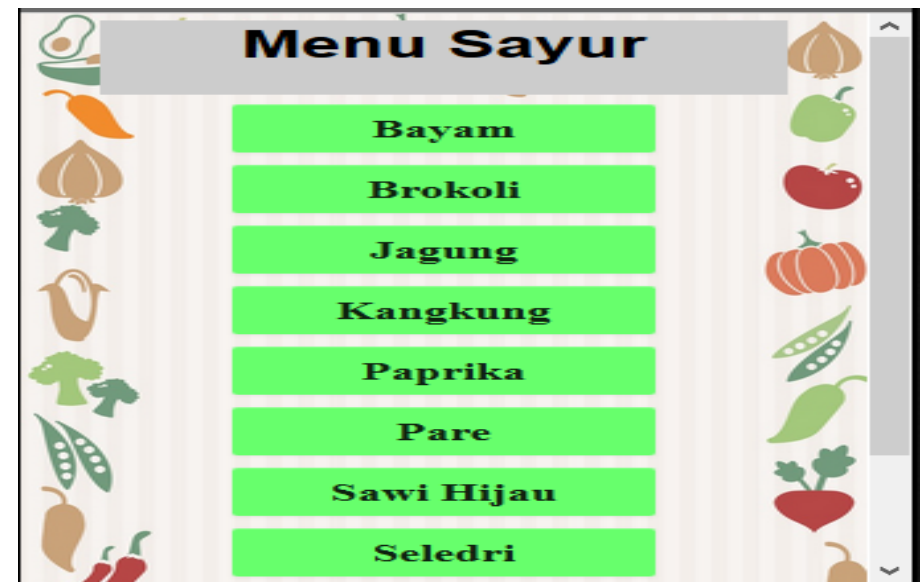

Gambar 9. Tampilan Menu Sayur

Halaman Menu Sayur ini berisikan beberapa pilihan menu sayur

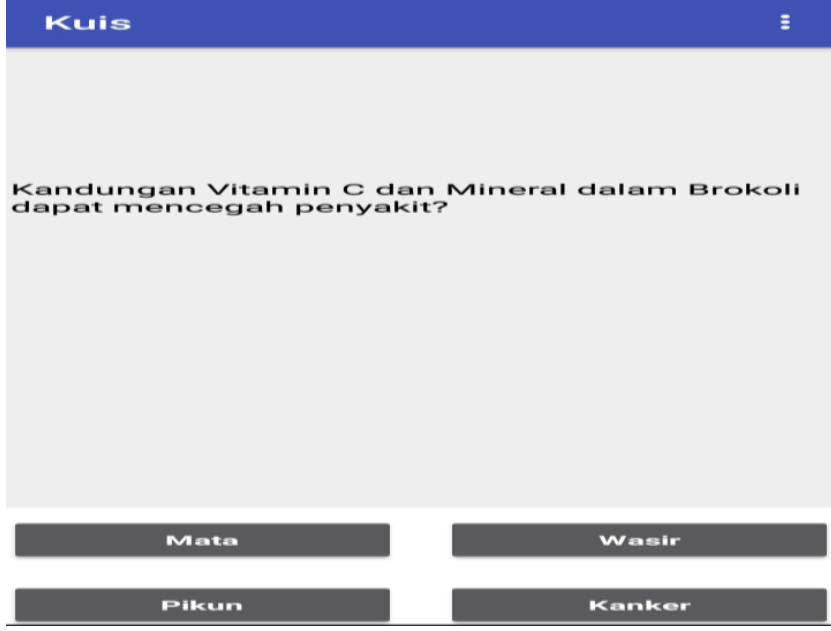

Gambar 10. Tampilan Menu Kuis

Pada Tampilan Menu Kuis berisi soal-soal yang berhubungan dengan buah dan sayuran. 


\section{SIMPULAN}

Berdasarkan hasil perancangan sistem yang peneliti lakukan, maka peneliti melakukan kesimpulan dan mengajukan beberapa saran-saran yang berhubungan dengan pembahasan yang ditemukan pada pembahasan sebelumnya diantaranya, Aplikasi Edukasi vitamin Pada Buah-Buahan dan Sayur-Sayuran dapat digunakan oleh para pengguna sebagai media alternatif untuk mengetahui manfaat yang terkandung dalam buah dan sayur kapanpun dan dimanapun melalui aplikasi berbasis android, Aplikasi ini memberikan kemudahan masyarakat untuk memahami dan mempelajarinya. Kelemahan aplikasi ini yaitu untuk saat ini hanya dapat dijalankan diplatfrom android.

\section{DAFTAR PUSTAKA}

Atmodjo, G., \& Krisjanti, M. (2016). Preferensi Konsumen Terhadap Merek Smartphone Berdasarkan Sistem Operasi. $1-15$.

Chusna, P. A. (2017). Pengaruh Media Gadget Pada Perkembangan Karakter Anak. Dinamika Penelitian: Media Komunikasi Sosial Keagamaan, 17(2), 315-330. https://e-resources.perpusnas.go.id:2093/doi/abs/10.1142/S019 2415X20500500

Dwiningrum, S. (2012). Ilmu Sosial \& Budaya Dasar. UNY Press.

Firmansyah, F. (2017). Menkes Ajak Masyarakat Makan Sayur dan Buah Setiap Hari. Kesmas.Kemkes.Go.Id/. https://kesmas.kemkes.go.id/konten/133/0/020114-Germas

Furqan, S. A. (2015). Aplikasi Nama Ilmiah Hewan dan Tumbuhan Berbasis Android. Universitas Indraprasta PGRI Jakarta.

Jocom, N. (2013). Peran Smartphone Dalam Menunjang Kinerja Karyawan Bank Prismadana (Studi Pada Karyawan Bank Prismadana Cabang Airmadidi). Journal "Acta Diurna."

Nazruddin Safaat. (2011). Pemrograman Aplikasi Mobile Smartphone dan Tablet PC Berbasis Android. In Android.

Sugiarto, E. (2015). Menyusun Proposal Penelitian Kualitatif Skripsi dan Tesis. Penelitian.

Sugiyono. (2016). Sugiyono, Metode Penelitian. Sugiyono.

Sutabri Tata. (2012). Analisa Sistem Informasi. Andi Yogyakarta. 